\title{
PERAN KELUARGA, SEKOLAH, DAN MASYARAKAT DALAM PEMBENTUKAN KARAKTER BERKUALITAS
}

\author{
Jito Subianto \\ LPPG (Lembaga Peningkatan Profesi Guru), \\ Jawa Tengah, Indonesia \\ jito.subiyanto@yahoo.com
}

\begin{abstract}
Abstrak
Pendidikan karakter merupakan langkah sangat penting dan strategis dalam membangun kembali jati diri bangsa dan menggalang pembentukan masyarakat Indonesia baru. Pendekatan dalam penelitian ini adalah studi kepustakaan. Hasil kajian ini menunjukkan bahwa membentuk siswa yang berkarakter bukan suatu upaya mudah dan cepat. Hal tersebut memerlukan upaya terus menerus dan refleksi mendalam untuk membuat rentetan (Moral Choice) keputusan moral yang harus ditindaklanjuti dengan aksi nyata, sehingga menjadi hal yang praktis dan reflektif. Diperlukan sejumlah waktu untuk membuat semua itu menjadi (custom) kebiasaan dan membentuk watak atau tabiat seseorang. Karakter pendidikan harus melibatkan berbagai pihak, di keluarga dan rumah tangga, lingkungan sekolah, dan masyarakat. Hal ini merupakan langkah utama yang harus dilakukan ialah menyambung kembali hubungan dan jaringan pendidikan yang nyaris putus diantara ketiga lingkungan pendidikan tersebut. Pembentukan sifat dan karakter pendidikan tidak akan pernah berhasil selama diantara ketiga lingkungan pendidikan tidak ada keharmonisan dan kesinambungan. Melihat kenyataan ini, membentuk karakter siswa yang berkualitas diperlukan pengaruh yang kuat dari keluarga, sekolah, dan mayarakat.
\end{abstract}

Kata kunci: peran keluarga, sekolah, masyarakat, karakter 
Jito Subianto

\begin{abstract}
ROLE OF THE FAMILY, SCHOOL AND SOCIETY IN CREATING A QUALITY CHARACTER. Character education is a very important and strategic step in the rebuilding of national identity and mobilize the formation of new Indonesian society. This study uses library research. The result of this study is that forming character of students is not an easy and quick effort. It requires continuous effort and deep reflection to make a series of Moral Choice (moral judgment) that must be followed up with concrete action, so that it becomes practical and reflective. The necessary amount of time to make it into a custom (habit) and establish a character or a person's character. Character education should involve various stakeholders, in the family and household, school, and community. This is a major step that must be done is to reconnect the relationship and educational networks that breaking point between the third educational environment. The formation of the nature and character education will never succeed as long as the third among the educational environment there is no harmony and continuity.
\end{abstract}

Keywords: The role of family, school, community, character

\title{
A. Pendahuluan
}

Pendidikan adalah usaha meningkatkan diri dalam segala aspeknya. Pendidikan merupakan suatu yang integral dari kehidupan. Pendidikan berasal dari kata didik yang berarti memelihara dan membentuk latihan, jadi pendidikan adalah suatu usaha yang dilakukan secara sadar dan sengaja untuk mengubah tingkah laku manusia secara individu maupun kelompok untuk mendewasakan manusia melalui upaya pengajaran dan pelatihan.

Dewasa ini pemerintah mengalakan pendidikan yang bercirikan agama, atau yang sering disebut dengan pendidikan karakter. Pada dasarnya pendidikan karakter merupakan pola pendidikan umum yang di dalamnya ada muatan mata pelajaran bernuansakan agama. Yang dengan cita-cita dapat membekali anak didik dengan ilmu pengetahuan umum dan pengetahuan agama.

Dengan pengetahuan umum diharapkan anak didik mampu menghadapi kehidupan dunia, dan dengan pendidikan agama diharapkan kehidupan anak didik nantinya terarah, karena mempunyai tujuan yang pasti, yaitu bahagia dalam kehidupan dunia dan akhirat. 
Untuk mencapai kebahagiaan tersebut tentunya memerlukan komponen yang teramat penting yaitu kesadaran diri akan adanya pencipta dirinya dan pencipta alam semesta, yang akan berdampak pada kesadaran kepada adanya sang khalik yaitu yang disebut dengan Tuhan, dalam hal ini adalah Allah Swt. Dan kesadaran dan keyakinan akan adanya tuhan itu disebut dengan iman. Persoalan kita ialah bagaimana kita menanamkan rasa iman, rasa cinta kepada Allah, rasa nikmat beribadah (salat, puasa, dan lain-lain), rasa hormat pada kedua orang tua, dan sebagainya.

Fenomena melorotnya akhlak generasi bangsa, termasuk di dalamnya para elit bangsa, acapkali menjadi apologi bagi sebagian orang untuk memberikan kritik pedasnya terhadap institusi pendidikan. Hal tersebut teramat wajar karena pendidikan sesungguhnya memiliki misi yang amat mendasar yakni membentuk manusia utuh dengan akhlak mulia sebagai salah satu indikator utama, generasi bangsa dengan karatekter akhlak mulia merupakan salah satu profil yang diharapkan dari praktek pendidikan nasional.

Adanya kata-kata berakhlak mulia dalam rumusan tujuan pendidikan nasional di atas mengisyaratkan bahwa bangsa Indonesia mencita-citakan agar akhlak mulia menjadi bagian dari karakter nasional. Hal tersebut diharapkan dapat terwujud melalui proses pendidikan nasional yang dilakukan secar berjenjang dan berkelanjutan. Terlebih bangsa Indonesia dengan mayoritas muslim menjadi daya dukung tersendiri bagi terwujudnya masyarakat dengan akhlak yang dilandasi oleh nilai-nilai Islam. Hal tersebut dikarenakan akhlak menjadi bagian integral dari struktur ajaran Islam (akidah, syariah dan akhlak).

Terkait dengan pendidikan berbasis karakter, Koesoema (2010: 135) mengemukakan bahwa pendidikan karakter hanya akan menjadi sekadar wacana jika tidak dipahami secara lebih utuh dan menyeluruh dalam konteks pendidikan nasional kita. Bahkan, pendidikan karakter yang dipahami secara parsial dan tidak tepat sasaran justru malah bersifat kontraproduktif bagi pembentukan karakter anak didik. Pendekatan parsial yang tidak didasari pendekatan pedagogi yang kokoh alih-alih menanamkan nilai-nilai keutamaan dalam diri anak, malah menjerumuskan mereka pada perilaku kurang bermoral. 
Lebih lanjut, Koesoema (2010:2) memberikan formula bahwa pendidikan karakter jika ingin efektif dan utuh harus menyertakan tiga basis desain dalam pemogramannya.

1. 1. Desain pendidikan karakter berbasis kelas. Desain ini berbasis pada relasi guru sebagai pendidik dan siswa sebagai pembelajar di dalam kelas. Konteks pendidikan karakter adalah proses relasional komunitas kelas dalam konteks pembelajaran. Relasi guru-pembelajar bukan monolog, melainkan dialog dengan banyak arah sebab komunitas kelas terdiri dari guru dan siswa yang sama-sama berinteraksi dengan materi. Memberikan pemahaman dan pengertian akan keutamaan yang benar terjadi dalam konteks pengajaran ini, termasuk di dalamnya pula adalah ranah noninstruksional, seperti manajemen kelas, konsensus kelas, dan lain-lain, yang membantu terciptanya suasana belajar yang nyaman.

2. Desain pendidikan karakter berbasis kultur sekolah. Desain ini mencoba membangun kultur sekolah yang mampu membentuk karakter anak didik dengan bantuan pranata sosial sekolah agar nilai tertentu terbentuk dan terbatinkan dalam diri siswa. Untuk menanamkan nilai kejujuran tidak cukup hanya dengan memberikan pesan-pesan moral kepada anak didik. Pesan moral ini mesti diperkuat dengan penciptaan kultur kejujuran melalui pembuatan tata peraturan sekolah yang tegas dan konsisten terhadap setiap perilaku ketidakjujuran.

3. Desain pendidikan karakter berbasis komunitas. Dalam mendidik, komunitas sekolah tidak berjuang sendirian. Masyarakat di luar lembaga pendidikan, seperti keluarga, masyarakat umum, dan negara, juga memiliki tanggung jawab moral untuk mengintegrasikan pembentukan karakter dalam konteks kehidupan mereka. Ketika lembaga negara lemah dalam penegakan hukum, ketika mereka yang bersalah tidak pernah mendapatkan sanksi yang setimpal, negara telah mendidik masyarakatnya untuk menjadi manusia yang tidak menghargai makna tatanan sosial bersama. 


\section{B. Pembahasan}

\section{Nilai-nilai dalam Pendidikan Karakter}

Karakter ialah perilaku nilai-nilai manusia yang berhubungan dengan Tuhan Yang maha Esa, sesama manusia, lingkungan, diri sendiri, dan kebangsaan yang terwujud didalam adat istiadat, budaya, tata karma, hokum, pemikiran, sikap, perasaan, perkataan, dan perbuatan berdasarkan norma-norma agama.

Lickona mengatakan bahwa karakter pendidikan ialah suatu upaya yang disengaja untuk membantu seseorang sehingga seseorang tersebut dapat melakukan nilai-nilai etika yang inti, memperhatikan dan memahaminya. Karakter pendidikan, membutuhkan metode khusus yang tepat agar tujuan pendidikan bisa tercapai, Diantaranya metode pembelajaran yang sudah sesuai ialah metode pujian dan hukuman, metode pembiasaan, dan metode keteladanan.

Karakter yang mutlak dibutuhkan bukan hanya di lingkungan sekolah saja, tetapi di lingkungan sosial dan juga di lingkungan rumah. Bahkan sekarang ini pesertanya bukan lagi anak usia dini hingga remaja, yapi juga meliputi usia dewasa. Di zaman ini kita akan berhadapan dengan persaingan termasuk rekan-rekan diberbagai belahan negara di dunia. Bahkan kita pun yang masih berkarya di tahun ini pasti akan merasa perasaan yang sama. Tuntutan dari berbagai kualitas SDM pada tahun 2021 mendatang tentunya akan membutuhkan karakter yang baik. Karakter merupakan kunci dari salah satu keberhasilan individu. Berdasarkan penelitian bahwa $80 \%$ keberhasilan untuk seseorang di masyarakat ditentukan oleh (EQ). Karakter pendidikan telah menjadi pusat perhatian di berbagai belahan dunia dalam rangka menyiapkan generasi yang baik, tidak hanya untuk kepentingan individu warga negaranya saja tetapi untuk keseluruhan warga masyarakat. Pendidikan karakter bisa diartikan sebagai usaha kita secara sengaja dari seluruh dimensi kehidupan sekolah/madrasah untuk membentu pembentukan karakter secara optimal.

Pembentukan ialah bagian dari pendidikan nilai melalui sekolah yang merupakan usaha mulia yang mendesak harus dilakukan. Ada 18 poin nilai-nilai karakter pendidikan: tanggungjawab, Peduli sosial, Peduli lingkungan, Gemar membaca, Cinta Damai, Bersahabat/Komunikatif, Menghargai prestasi, Cinta tanah air, 
Semangat kebangsaan, Rasa ingin tahu, Demokratis, Toleransi, Jujur, Disiplin, kreatif, Kerja keras, Religius, Mandiri. Pembentukan karakter merupakan bagian dari pendidikan nilai (values education) melalui sekolah merupakan usaha mulia yang mendesak untuk dilakukan. Bahkan, kalau kita berbicara tentang masa depan, sekolah bertanggungjawab bukan hanya dalam mencetak peserta didik yang unggul dalam ilmu pengetahuan dan teknologi, tetapi juga dalam jati diri, karakter dan kepribadian. Dan hal ini relevan dan kontekstual bukan hanya di negara-negara yang tengah mengalami krisis watak seperti Indonesia, tetapi juga bagi negara-negara maju sekalipun (Fraenkel 1977: 2).

Karakter pendidikan sekarang ini juga berarti melakukan usaha yang sungguh-sungguh, sistematik dan tentunya berkelanjutan untuk membangun dan menguatkan kesadaran pada keyakinan semua orang di Indonesia bahwa masa depan yang lebih baik akan hilang tanpa dibangunnya dan dikuatkannya karakter rakyat Indonesia. Seperti halnya, tidak aka nada masa depan yang lebih baik yang bisa diwujudkan tanpa kegigihan, tanpa meningkatkan disiplin diri, tanpa kejujuran, tanpa semangat belajar yang tinggi, tanpa memupuk persatuan di tengah-tengah kebinekaan, tanpa mengembangkan rasa tanggungjawab, tanpa semangat berkontribusi bagi kemajuan bersama, dan serta tanpa optimisme. Untuk mendidik seseorang dalam aspek kecerdasan otak bukan aspek moral adalah ancaman marabahaya kepada masyarakat. Sekolah juga berperan untuk membentuk karakter seorang anak.

Pendidikan karakter merupakan langkah sangat penting dan strategis dalam membangun kembali jati diri bangsa dan menggalang pembentukan masyarakat Indonesia baru. Tetapi penting untuk segara dikemukakan sebagaimana terlihat dalam pernyataan Phillips bahwa pendidikan karakter haruslah melibatkan semua pihak; rumah tangga dan keluarga; sekolah; dan lingkungan sekolah lebih luas (masyarakat). Karena itu, langkah pertama yang harus dilakukan adalah menyambung kembali hubungan dan educational networks yang nyaris terputus antara ketiga lingkungan pendidikan ini. Pembentukan watak dan pendidikan karakter tidak akan berhasil selama antara ketiga lingkungan pendidikan tidak ada kesinambungan dan harmonisasi. 


\section{Peran Keluarga}

Pendidikan adalah tanggung jawab bersama antara keluarga, sekolah, masyarakat atau pemerintah. Sekolah sebagai pembentuk kelanjutan pendidikan dalam keluarga, sebab pendidikan yang pertama dan utama diperoleh anak adalah dalam keluarga.

Menurut Sayyidina Ali bin Abi Thalib (RA), seorang sahabat utama Rasulullah Muhammad (SAW) menganjurkan: Ajaklah anak pada usia sejak lahir sampai tujuh tahun bermain, ajarkan anak peraturan atau adab ketika mereka berusia tujuh sampai empat belas tahun, pada usia empat belas sampai dua puluh satu tahun jadikanlah anak sebagai mitra orang tuanya. Ketika anak masuk ke sekolah mengikuti pendidikan formal, dasar-dasar karakter ini sudah terbentuk. Anak yang sudah memiliki watak yang baik biasanya memiliki achievement motivation yang lebih tinggi karena perpaduan antara intelligence quotient, emosional quotient dan spiritual quotient sudah terformat dengan baik.

Peran orang tua dalam mewujudkan kepribadian anak antara lain:

1. Kedua orang tua harus mencintai dan menyayangi anakanaknya

2. Kedua orang tua harus menjaga ketenangan lingkungan rumah dan menyiapkan ktenangan jiwa anak-anak

3. Saling menghormati antara kedua orang tua dan anak-anak

4. Mewujudkan kepercayaan

5. Mengadakan kumpulan dan rapat keluarga (kedua orang tua dan anak)

Selain itu kedua orang tua harus mengenalkan mereka tentang masalah keyakinan, akhlak dan hukum-hukum fikih serta kehidupan manusia. Yang paling penting adalah bahwa ayah dan ibu adalah satusatunya teladan yang pertama bagi anak-anaknya dalam pembentukan kepribadian, begitu juga anak yang secara tidak sadar mereka akan terpengaruh, maka kedua orang tua di sisni berperan sebagai teladan bagi mereka baik teladan pada tataean teoritis maupun praktis.

Seperti yang telah dijelaskan, bahwa lingkungan rumah dan keluarga memiliki andil yang sangat besar dalam pembentukan perilaku anak. Untuk itu pastilah ada usaha yang harus dilakukan 
terutama oleh pihak-pihak yang terkait didalamnya sehingga mereka akan memiliki tanggung jawab dalam hal ini. Beberapa contoh kebiasaan yang dapat dilakukan di lingkungan keluarga:

1. Membiasakan anak bangun pagi, mengatur tempat tidur dan berolahraga

2. Membiasakan anak mandi dan berpakaian bersih

3. Membiasakan anak turut membantu mengerjakan tugastugas rumah

4. Membiasakan anak mengatur dan memelihara barang-barang yang dimilikinya

5. Membiasakan dan mendampingi anak belajar/mengulang pelajaran/ mengerjakan tugas sekolahnya

6. Membiasakan anak pamit jika keluar rumah

7. Membiasakan anak mengucap salam saat keluar dari dan pulang ke rumah

8. Menerapkan pelaksanaan ibadah shalat sendiri dan berjamaah

9. Mengadakan pengajian Alquran dan ceramah agama dalam keluarga

10. Menerapkan musyawarah dan mufakat dalam keluarga sehingga dalam diri anak akan tumbuh jiwa demokratis

11. Membiasakan anak bersikap sopan santun kepada orang tua dan tamu

12. Membiasakan anak menyantuni anak yatim dan fakir miskin Kendala-kendala yang dihadapi dalam keluarga :

1. idak ada/kurangnya keteladanan/contoh penerapan yang diberikan oleh orang tua.

2. Orang tua atau salah satu anggota keluarga (orang dewasa) yang tidak konsisten dalam melaksanakan usaha yang sedang diterapkan

3. Kurang terpenuhinya kebutuhan anak dalam keluarga, baik secara fisik maupun psikhis sebab ada ungkapan yang menyatakan bahwa 'kepatuhan anak berbanding sama dengan kasih sayang yang diterimanya.

4. Tempat tinggal yang tidak menetap

Rumah tangga dan keluarga sebagai lingkungan pembentukan watak dan pendidikan karakter pertama dan utama mestilah 
diberdayakan kembali. Sebagaimana disarankan Phillips, keluarga hendaklah kembali menjadi "school of love", sekolah untuk kasih sayang (Phillips 2000: 11). Dalam perspektif Islam, keluarga sebagai "school of love" dapat disebut sebagai "madrasah mawaddah wa rahmah, tempat belajar yang penuh cinta sejati dan kasih sayang.

Islam memberikan perhatian yang sangat besar kepada pembinaan keluarga (usrah). Keluarga merupakan basis dari (ummah) bangsa; dan karena itu keadaan keluarga sangat menentukan keadaan ummah itu sendiri. Bangsa terbaik (khayr ummah) yang merupakan (ummah wahidah) bangsa yang satu dan (ummah wasath) bangsa yang moderat, sebagaimana dicita-citakan Islam hanya dapat terbentuk melalui keluarga yang dibangun dan dikembangkan atas dasar mawaddah warahmah.

Berdasarkan sebuah hadis yang diriwayatkan Anas r.a, keluarga yang baik memiliki empat ciri. Pertama; keluarga yang memiliki semangat (ghirah) dan kecintaan untuk mempelajari dan menghayati ajaran-ajaran agama dengan sebaik-baiknya untuk kemudian mengamalkan dan mengaktualisasikannya dalam kehidupan seharihari. Kedua, keluarga di mana setiap anggotanya saling menghormati dan menyayangi; saling asah dan asuh. Ketiga, keluarga yang dari segi nafkah (konsumsi) tidak berlebih-lebihan; tidak ngoyo atau tidak serakah dalam usaha mendapatkan nafkah; sederhana atau tidak konsumtif dalam pembelanjaan. Keempat, keluarga yang sadar akan kelemahan dan kekurangannya; dan karena itu selalu berusaha meningkatkan ilmu dan pengetahuan setiap anggota keluarganya melalui proses belajar dan pendidikan seumur hidup (life long learning), min al-mahdi ila al-lahdi.

\section{a. Pembinaan karakter anak yang dilakukan oleh keluarga}

Secara etimologi pengasuhan berasal dari kata "asuh" yang artinya, pemimpin, pengelola, membimbing. Oleh kerena itu mengasuh disini adalah mendidik dan memelihara anak itu, mengurus makan, minum, pakaiannya dan keberhasilannya dari periode awal hingga dewasa. Pada dasarnya, tugas dasar perkembangan anak adalah mengembangkan pemahaman yang benar tentang bagaimana dunia ini bekerja. Dengan kata lain, tugas utama seorang anak dalam perkembangannya adalah mempelajari "aturan main” segala aspek yang 
ada di dunia ini. Berbagai pola asuh orang tua dapat mempengaruhi kreativitas anak antara lain, lingkungan fisik, lingkungan sosial pendidikan internal dan eksternal. Intensitas kebutuhan anak untuk mendapatkan bantuan dari orang tua bagi kepemilikan dan pengembangan dasar-dasar kreativitas diri, menunjukan adanya kebutuhan internal yaitu manakala anak masih membutuhkan banyak bantuan dari orang tua untuk memiiliki dan mengembangkan dasardasar kreativitas diri (berdasarkan naluri), berdasarkan nalar dan berdasarkan kata hati. Dari hasil penelitian bahwa bila orang tua berperan dalam pendidikan, anak akan menunjukan peningkatan prestasi belajar, diikuti dengan perbaikan sikap, stabilitas sosioemosional, kedisiplinan, serta aspirasi anak untuk belajar sampai ke jenjang paling tinggi, bahkan akan membantu anak ketika ia telah bekerja dan berkeluarga.

\section{b. Keluarga sebagai wahana pertama dan utama pendidikan}

Para sosiolog meyakini bahwa keluarga memiliki peran penting dalam menentukan kemajuan suatu bangsa, sehingga mereka berteori bahwa keluarga adalah unit yang penting sekali dalam masyarakat. Oleh karena itu para sosiolog yakin, segala macam kebobrokan masyarakat merupakan akibat lemahnya institusi keluarga. Bagi seorang anak keluarga merupakan tempat pertama dan utama bagi pertumbuhan dan perkembangnnya. Menurut resolusi Majelis Umum PBB, fungsi utama keluarga adalah sebagai wahana untuk mendidik, mengasuh dan mensosialisasikan anak, mengembangkan kemampuan seluruh anggotanya agar dapat menjalankan fungsinya di masyarakat dengan baik, serta, memberikan kepuasan dan lingkungan yang sehat guna tercapainya keluarga sejahtera”. Keluarga merupakan tempat yang paling awal dan efektif untuk menjalankan fungsi departemen kesehatan, pendidikan adan kesejahteraan. Jika keluarga gagal untuk mengajarkan kejujuran, semangat, keinginan untuk menjadi yang terbaik, dan menguasai kemampuan- kemampuan dasar, maka akan sulit sekali bagoi institusi lain untuk memperbaiki kegagalannya. Karena kagagalan keluarga dalam membentuk karakter anak akan berakibat pada tumbuhnya masyarakat yang berkarakter buruk atau tidak berkarakter. Oleh karena itu setiap keluarga harus memiliki kesadaran bahwa karakter bangsa sangat tergantung pada pendidikan karakter anak di rumah. 


\section{c. Pola asuh menentukan keberhasilan pendidikan anak dalam keluarga}

Keberhasilan keluarga dalam menanamkan nilai-nilai kebijakan pada anak sangat tergantung pada jenis pola asuh yang diterapkan orang tua pada anaknya. Pola asuh dapat didefinisikan sebagai pola interaksi antara anak dengan orang tua yang meliputi pemenuhan kebutuhan fisik dan kebutuhan psikologis, serta normanorma yang berlaku di masyarakat.agar anak dapat hidup selaras dengan lingkungannya. Beberapa macam contoh pola asuh:

1. Pola asuh otoriter, yaitu mempunyai ciri, kekuasan orang tua dominan, anak tidak diakui sebagai pribadi, control terhadap tingkah laku anak sangat ketat, orang tua menghukum anak jika tidak patuh.

2. Pola asuh demokratis, kerjasama antara orang tua- anak, anak diakui sebgai pribadi, ada bimbingan dan penngarahan dari orang tua, control orang tua tidak kaku.

3. Pola asuh permisif, mempunyai ciri, dominasi oleh anak, sikap longgar atau kebebasan dari orang tua, kontrol dan perhatian orang tua sangat kurang. Melalui pola asuh yang dilakukan orang tua anak akan belajar banyak hal, termasuk karakter. Artinya jenis pola asuh yang ditetapkan orang tua terhadap anaknya menentukan keberhasilan pendidikan karakter anak oleh keluarga.

\section{d. Kesalahan keluarga dalam mendidik anak mempengaruhi perkembangan kecerdasan emosi anak}

Kesalahan dalam pengasuhan anak akan berakibat pada kegagalan dalam pembentukan karakter yang baik. Beberapa kesalahan orang tua dalam mendidik anak dapat mempengaruhi kecerdasan emosi anak, diantaranya adalah:

1. Orang tua kurang menunjukan ekspresi kasih sayang baik secara verbal maupun fisik

2. Kurang meluangkan waktu untuk anak

3. Orang tua bersikap kasar secara verbal, misalnya, menyindir anak, mengecilkan anak dan berkata kata kasar

4. Bersikap kasar secara fisik, misalnya memukul, mencubit atau memberikan hukuman badan lainnya. 
Jito Subianto

5. Orang tua terlalu memaksa anak untuk menguasai kemampuan kognitif secara dini

6. Orang tua tidak menanamkan karakter yang baik pada anak

Dampak salah asuh diatas akan menimbulkan anak yang mempunyai kepribadian yang bermasalah atau kecedasan emosi yang rendah, seperti:

1. Anak menjadi tak acuh, tidak menerima persahabatan, rasa tidak percaya pada orang lain dll.

2. Secara emosionil tidak responsif

3. Berprilaku agresif

4. Menjadi minder

5. Selalu berpandangan negatif

6. Emosi tidak stabil

7. Emosional dan intelektual tidak seimbang dan lain-lain.

\section{Peran Sekolah}

Jika dilingkungan rumah/ keluarga, anak dapat dikatakan "menerima apa adanya" dalam menerapkan sesuatu perbuatan, maka dilingkungan sekolah sesuatu hal menjadi "mutlak"adanya, sehingga kita sering mendengar anak mengatakan pada orang tuanya "Ma, $\mathrm{Pa}$, kata $\mathrm{Bu}$ guru/ Pak guru begini bukan begitu "Ini menunjukkan bahwa pengaruh sekolah sangat besar dalam membentuk pola pikir dan karakter anak, namun hal ini pun bukanlah sesuatu yang mudah tercapai tanpa ada usaha yang dilakukan. Untuk menjadi 'Bapak dan Ibu' guru seperti dalam ilustrasi diatas butuh keteladanan dan konsistensi perilaku yang patut diteladani. Contoh-contoh perilaku yang dapat diterapkan di sekolah:

1. Membiasakan siswa berbudaya salam, sapa dan senyum

2. Tiba di sekolah mengucap salam sambil salaman dan cium tangan guru.

3. Menyapa teman, satpam, penjual dikantin atau cleaning servis di sekolah

4. Menyapa dengan sopan tamu yang datang ke sekolah

5. Membiasakan siswa berbicara dengan bahasa yang baik dan santun

6. Mendidik siswa duduk dengan sopan di kelas

7. Mendidik siswa makan sambil duduk di tempat yang telah disediakan, tidak sambil jalan- jalan 
8. Membimbing dan membiasakan siswa shalat Dhuha dan shalat Dzuhur berjamaah di sekolah

Kendala - kendala yang dihadapi di sekolah:

1. idak ada / kurangnya keteladanan / contoh yang diberikan

2. Guru yang tidak konsisten dalam melaksanakan aturan yang telah ditetapkan

3. Lingkungan sekolah yang tidak kondusif untuk pembelajaran

Sekolah, pada hakikatnya bukanlah sekedar tempat "transfer of knowledge" belaka. Seperti dikemukakan Fraenkel (1977: 1-2), sekolah tidaklah semata-mata tempat di mana guru menyampaikan pengetahuan melalui berbagai mata pelajaran. Sekolah juga adalah lembaga yang mengusahakan usaha dan proses pembelajaran yang berorientasi pada nilai (value-oriented enterprise).

Pembentukan karakter merupakan bagian dari pendidikan nilai (values education) melalui sekolah merupakan usaha mulia yang mendesak untuk dilakukan. Bahkan, kalau kita berbicara tentang masa depan, sekolah bertanggungjawab bukan hanya dalam mencetak peserta didik yang unggul dalam ilmu pengetahuan dan teknologi, tetapi juga dalam jati diri, karakter dan kepribadian.

Usaha pembentukan watak melalui sekolah, secara berbarengan dapat pula dilakukan melalui pendidikan nilai dengan langkah-langkah sebagai berikut: Pertama, menerapkan pendekatan "modelling" atau "exemplary" atau "uswah hasanah". Yakni mensosialisasikan dan membiasakan lingkungan sekolah untuk menghidupkan dan menegakkan nilai-nilai akhlak dan moral yang benar melalui model atau teladan. Setiap guru dan tenaga kependidikan lain di lingkungan sekolah hendaklah mampu menjadi "uswah hasanah" yang hidup (living exemplary) bagi setiap peserta didik. Mereka juga harus terbuka dan siap untuk mendiskusikan dengan peserta didik tentang berbagai nilai-nilai yang baik tersebut.

Kedua, menjelaskan atau mengklarifikasikan kepada peserta didik secara terus menerus tentang berbagai nilai yang baik dan yang buruk. Usaha ini bisa dibarengi pula dengan langkah-langkah; memberi penghargaan (prizing) dan menumbuhsuburkan (cherising) nilai-nilai yang baik dan sebaliknya mengecam dan mencegah (discouraging) berlakunya nilai-nilai yang buruk; menegaskan nilai- 
nilai yang baik dan buruk secara terbuka dan kontinu; memberikan kesempatan kepada peserta didik untuk memilih berbagai alternatif sikap dan tindakan berdasarkan nilai; melakukan pilihan secara bebas setelah menimbang dalam-dalam berbagai konsekuensi dari setiap pilihan dan tindakan; membiasakan bersikap dan bertindak atas niat dan prasangka baik (husn al-zhan) dan tujuan-tujuan ideal; membiasakan bersikap dan bertindak dengan pola-pola yang baik yang diulangi secara terus menerus dan konsisten.

Ketiga, menerapkan pendidikan berdasarkan karakter (character-based education). Hal ini bisa dilakukan dengan menerapkan character-based approach ke dalam setiap mata pelajaran nilai yang ada di samping matapelajaran-mata pelajaran khusus untuk pendidikan karakter, seperti pelajaran agama, pendidikan kewarganegaraan (PKn), sejarah, Pancasila dan sebagainya.

Pembentukan watak dan pendidikan karakter melalui sekolah, dengan demikian, tidak bisa dilakukan semata-mata melalui pembelajaran pengetahuan, tetapi adalah melalui penanaman atau pendidikan nilai-nilai. Apakah nilai-nilai tersebut? Secara umum, kajian-kajian tentang nilai biasanya mencakup dua bidang pokok, estetika, dan etika (atau akhlak, moral, budi pekerti). Estetika mengacu kepada hal-hal tentang dan justifikasi terhadap apa yang dipandang manusia sebagai "indah", apa yang mereka senangi. Sedangkan etika mengacu kepada hal-hal tentang dan justifikasi terhadap tingkah laku yang pantas berdasarkan standar-standar yang berlaku dalam masyarakat, baik yang bersumber dari agama, adat istiadat, konvensi, dan sebagainya. Dan standar-standar itu adalah nilai-nilai moral atau akhlak tentang tindakan mana yang baik dan mana yang buruk.

Sekolah merupakan sarana yang secara sengaja dirancang untuk melaksanakan pendidikan. Karena kemajuan zaman, maka keluarga tidak mungkin lagi memenuhi seluruh kebutuhan dan aspirasi anak terhadap iptek. Semakin maju suatu masyarakat, semakin penting peranan sekolah dalam mempersiapkan generasi muda sebelum masuk dalam proses pembangunan masyarakat itu. Suatu alternatif yang mungkin dilakukan untuk meningkatkan sekolah dalam perannyasebagai lembaga pendidikan sesuai dengan situasi dan kondisi sekolah, antara lain: 


\section{a. Pengajaran yang mendidik}

Yaitu pengajaran yang serentak memberi peluang pencapaian tujuan intruksional bidang studi dan tujuan-tujuan umum pendidikan lainnya. Dalam upaya mewujudkan pengajaran yang mendidik, perlu dikemukakan bahwa setiap keputusan dan tindakan guru dalam rangka kegiatan belajar mengajar akan membawa berbagai dampak atau efek kepada siswa, Pemilihan kegiatan belajar yang etpat, akan memberikan pengalaman belajar siswa yang efisien dan efektif untuk mewujudkan pembangunan manusia seutuhya. Hal ini dapat dilaksanakan dengan konsisten apabila guru memiliki wawasan kependidikan yang tepat serta menguasai berbagai strategi belajar mengajar sehingga mampu dan mau merancang dan melaksanakan berbagai kegiatan belajar mengajar yang kaya dan bermakna bagi peserta didik. Selain itu, pemberian prakarsa dan tanggung jawab sedini mungkin kepada anak dalam kegiatan belajar mengajar akan memupuk kebiasaan dan kemampuan belajar mandiri yang terus menerus. Dengan demikian diharapkan peran sekolah dapat mewujudkan suatu masyarakat yang cerdas.

\section{b. Peningkatan dan pemantapan program bimbingan dan penyuluhan (BP) di sekolah}

Seperti diketahui, bidang garapan program BP adalah perkembangan pribadi peserta didik, khususnya aspek sikap dan perilaku atau kawasan afektif. Dalam pedoman kurikulum disebutkan bahwa, Pelaksanaan kegiatan BP di sekolah menitikberatkan kepada bimbingan terhadap perkembangan pribadi melalui pendekatan perseorangan dan kelompok. Siswa yang menghadapi masalah mendapat bantuan khusus agar mampu mengatasi masalahnya. Semua siswa tetap mendapatkan bimbingan karier. Pendidikan afektif dapat diawali dengan kajian tentang nilai dan sikap yang seharusnya dikejar lebih jauh dalam perwujudannya melalui perilaku sehari-hari.

\section{c. Pengembangan perpustakaan sekolah}

Perpustakaan sekolah merupakan salah satu pusat sumber belajar, yang mengelola bukan hanya bahan pustaka tetapi juga berbagai sumber belajar lainnya. Perpustakan diharapkan peranannya bisa lebih aktif dalam mendukung program pendidikan. Dengan penyediaan berbagai perangkat lunak yang didukung perangkat 
keras yang memadai maka perpustakaan dapat menjadi "mitra kelas" dalam proses belajar mengajar dan tempat pengkajian berbagai pengembangan sistem instruksional. Suatu perpustakaan sekolah yang memadai akan dapat mendorong siswa atau anak untuk belajar mandiri.

\section{d. Peningkatan Program pengelolaan sekolah}

Khususnya yang terkait dengan peserta didik, pengelola sekolah sebagai pusat pendidikan dan kebudayaan seharusnya merupakan refleksi dari suatu masyarakat yang beradab yang dicitacitakan oleh tujuan nasional. Gaya kerja pengelola umumnya, akan berpengaruh bukan hanya melalui kebijakannya tetapi juga aspek keteladanannya.

Selain diperlukan sosok guru ideal yang mampu membuat ramuan perencanaan pembelajaran berbasis pendidikan karakter, dukungan iklim dan budaya sekolah/madrasah pun akan sangat menentukan hasil dari proses internalisasi. Demikian halnya dengan ketersediaan sarana dan prasarana yang mendukung. Peran kepemimpinan dari seorang kepala madrasah akan sangat menentukan hal tersebut dapat terwujud. Disamping peran serta yang optimal dari seluruh perangkat sekolah/madrasah.

Selain melalui upaya di atas, apa yang diungkapkan oleh Bagir, dkk (2005: 108) dapat menjadi referensi para praktisi pendidikan di lingkungan persekolahan dalam mengembangkan strategi pendidikan karakter di lingkungan madrasah. Menurutnya bahwa terdapat empat tataran implementasi, yaitu tataran konseptual, institusional, operasional, dan arsitektural.

Dalam tataran konseptual, internalisasi pendidikan karakter dapat diwujudkan melalui perumusan visi, misi, tujuan dan program madrasah (rencana strategis madrasah), adapun secara institusional, integrasi dapat diwujudkan melalui pembentukan institution culture yang mencerminkan adanya misi pendidikan karakter, sedangkan dalam tataran operasional, rancangan kurikulum dan esktrakulikuler (Kurikulum Tingkat Satuan Pendidikan/KTSP) harus diramu sedemikian rupa sehingga nilai-nilai fundamental agama prihal akhlak mulia dan kajian ilmu/ilmiah prihal akhlak mulia terpadu secara koheren. Sementara secara arsitektural, internalisasi dapat 
diwujudkan melalui pembentukan lingkungan fisik yang berbasis pendidikan akhlak, seperti sarana ibadah yang lengkap, sarana laboratorium yang memadai, serta perpustakaan yang menyediakan buku-buku prihal akhlak mulia.

Adapun Sulhan (2010: 15-16) mengemukakan tentang beberapa langkah yang dapat dikembangkan oleh madrasah dalam melakukan proses pembentukan karakter pada siswa. Adapun langkah tersebut adalah sebagai berikut:

1. Memasukan konsep karakter pada setiap kegiatan pembelajaran dengan cara:

b. Menambahkan nilai kebaikan kepada anak (knowing the good)

c. Menggunakan cara yang dapat membuat anak memiliki alasan atau keinginan untuk berbuat baik (desiring the good)

d. Mengembangkan sikap mencintai untuk berbuat baik (loving the good)

5. Membuat slogan yang mampu menumbuhkan kebiasaan baik dalam segala tingkah laku masyarakat sekolah

6. Pemantauan secara kontinu. Pemantauan secara kontinu merupakan wujud dari pelaksanaan pembangunan karakter. Beberapa hal yang harus selalu dipantau diantaranya adalah:

a. Kedisiplinan masuk pesantren

b. Kebiasaan saat makan di kantin

c. Kebiasaan dalam berbicara

d. Kebiasaan ketika di masjid, dll

5. Penilaian orangtua. Rumah merupakan tempat pertama sebenarnya yang dihadapi anak. Rumah merupakan tempat pertama anak berkomunikasi dan bersosialisasi dengan lingkungannya. Untuk itulah, orangtua diberikan kesempatan untuk menilai anak, khususnya dalam pembentukan moral anak.

Selain pendekatan-pendekatan di atas, minimal terdapat empat strategi yang bisa menjadi alternatif pendidikan karakter di sekolah/madrasah:

1. Pendekatan Normatif, yakni mereka (perangkat madrasah) 
secara bersama-sama membuat tata kelola (good governence) atau tata tertib penyelenggaraan madrasah yang didalamnya dilandasi oleh nilai-nilai pendidikan karakter/akhlak, perumusan tata kelola ini penting dibuat secara bersama, bahkan melibatkan santri dan tidak bersifat top down dari pimpinan madrasah Sehingga terlahir tanggung jawab moral kolektif yang dapat melahirkan sistem kontrol sosial, yang pada giliranya mendorong terwujudnya institution culture yang penuh makna.

2. Pendekatan Model yakni mereka (perangkat madrasah), khususnya pimpinan madrasah berupaya untuk menjadi model dari tata tertib yang dirumuskan, ucap, sikap dan prilakunya menjadi perwujudan dari tata tertib yang disepakati bersama.

3. Pendekatan Reward and Punishmen yakni diberlakukanya sistem hadiah dan hukuman sebagai stimulus dan motivator terwujudnya tata kelola yang dibuat.

4. Pendekatan Suasana Belajar (baik suasana fisik maupun suasana psikis) yakni dengan mengkondisikan suasana belajar agar menjadi sumber inspirasi penyadaran nilai bagi seluruh perangkat madrasah, termasuk para siswa seperti dengan memasang visi madrasah, kata-kata hikmah, ayat-ayat $\mathrm{Al}$ Qur'an dan mutiara hadis di tempat-tempat yang selalu terlihat oleh siapapun yang ada di madrasah, memposisikan bangunan masjid di arena utama madrasah, memasang kaligrafi di setiap ruangan belajar santri, membiasakan membaca Al Qur'an setiap mengawali belajar dengan dipimpin guru, program shalat berjamaah, kuliah tujuh menit, perlombaan-perlombaan dan sebagainya.

Sistem pendidikan dan lingkungan sekolah yang mengayomi dapat memacu keinginan dalam setiap anak untuk mengembangkan rasa bangga pada diri mereka untuk selalu berusaha mencapai kemampuan terbaik mereka sebagai seorang yang seimbang dan berkembang secara utuh untuk mengembangkan kualitas dan keterampilan yang diperlukan sebagai pembelajar sejati dan sebagi bagian dari masyarakat global.

Demikianlah beberapa alternatif yang dapat dilakukan untuk meningkatkan fungsi sekolah sebagai salah satu pusat pendidikan. 


\section{Peran Masyarakat}

Masyarakat pun memiliki peran yang tidak kalah pentingnya dalam upaya pembentukan karakter anak bangsa. Dalam hal ini yang dimaksud dengan masyarakat disini adalah orang yang lebih tua yang "tidak dekat ", "tidak dikenal " "tidak memiliki ikatan famili " dengan anak tetapi saat itu ada di lingkungan sang anak atau melihat tingkah laku si anak. Orang-orang inilah yang dapat memberikan contoh, mengajak, atau melarang anak dalam melakukan suatau perbuatan.

Contoh-contoh perilaku yang dapat diterapkan oleh masyarakat:

1. Membiasakan gotong royong, misalnya: membersihkan halaman rumah masing-masing, membersihkan saluran air, menanami pekarangan rumah.

2. Membiasakan anak tidak membuang sampah dan meludah di jalan, merusak atau mencoret-coret fasilitas umum.

3. Menegur anak yang melakukan perbuatan yang tidak baik.

Kendala - kendala yang dihadapi dimasyarakat:

4. Tidak ada kepedulian

5. Tidak merasa bertanggung jawab

6. Menganggap perbuatan anak adalah hal yang sudah biasa

Lingkungan masyarakat luas jelas memiliki pengaruh besar terhadap keberhasilan penanaman nilai-nilai estetika dan etika untuk pembentukan karakter. Dari perspektif Islam, menurut Shihab (1996: 321), situasi kemasyarakatan dengan sistem nilai yang dianutnya, mempengaruhi sikap dan cara pandang masyarakat secara keseluruhan. Jika sistem nilai dan pandangan mereka terbatas pada "kini dan di sini", maka upaya dan ambisinya terbatas pada kini dan di sini pula.

Peran serta Masyarakat (PSM) dalam pendidikan memang sangat erat sekali berkait dengan pengubahan cara pandang masyarakat terhadap pendidikan. ini tentu saja bukan hal yang, mudah untuk dilakukan. Akan tetapi apabila tidak dimulai dan dilakukan dari sekarang, kapan rasa memiliki, kepedulian, keterlibatan, dan peran serta aktif masyarakat dengan tingkatan maksimal dapat diperolah dunia pendidikan. 
Jito Subianto

\section{1) Norma-norma Sosial Budaya}

Masyarakat sebagai pusat pendidikan ketiga sesudah keluarga dan sekolah, mempunyai sifat dan fungsi yang berbeda dengan ruang lingkup dengan batasan yang tidak jelas dan keanekaragaman bentuk kehidupan sosial serta berjenis-jenis budayanya. Masalah pendidikan di keluarga dan sekolah tidak bisa lepas dari nilai-nilai sosial budaya yang dijunjung tinggi oleh semua lapisan masyarakat. Setiap masyarakat, dimanapun berada pasti punya karakteristik sendiri sebagai norma khas di bidang sosial budaya yang berbeda dengan masyarakat yang lain.

Norma-norma yang terdapat di Masyarakat harus diikuti oleh warganya dan norma-norma itu berpengaruh dalam pembentukan kepribadian warganya dalam bertindak dan bersikap. Dan normanorma tersebut merupakan aturan-aturan yang ditularkan oleh generasi tua kepada generasi berikutnya. Penularan-penularan itu dilakukan dengan sadar dan bertujuan, hal ini merupakan proses dan peran pendidikan dalam masyarakat.

\section{2) Jenis jenis peran serta masyarakat dalam pendidikan}

Ada bermacam-macam tingkatan peran serta masyarakat dalam pembangunan pendidikan. Yang biasa diklasifikasikan dalam, dimulai dari tingkat terendah ke tingkat lebih tinggi, yaitu;

1. Peran serta dengan menggunakan jasa pelayanan yang tersedia.

Jenis ini adalah jenis tingkatan yang paling umum, pada tingkatan ini masyarakat hanya memanfaatkan jasa sekolah untuk pendidikan anak.

2. Peran serta secara pasif

Artinya, menyetujui dan menerima apa yang diputuskan lembaga pendidikan lain, kemudian menerima keputusan lembaga tersebut dan mematuhinya.

3. Peran serta dengan memberikan kontribusi dana, bahan, dan tenaga.

Pada jenis ini, masyarakat berpartisipasi dalam perawatan dan pembangunan fisik sarana dan prasaranan pendidikan dengan menyumbangkan dana, barang atau tenaga. 
4. Peran serta dalam pelayanan. Masyarakat terlibat dalam kegiatan belajar mengajar, misalnya membantu sekolah dalam bidang studi tertentu.

5. Peran serta sebagai pelaksana kegiatan yang didelegasikan misalnya, sekolah meminta masyarakat untuk memberikan penyuluhan pentingnya pendidikan, dan lain-lain.

6. Peran serta dalam pengambilan keputusan.

Masyarakat terlibat dalam pembahasan masalah pendidikan anak, baik akademis maupun non akademis. Dan ikut dalam proses pengambilan keputusan dalam rencana pengembangan pendidikan.

\section{Simpulan}

Penguatan pendidikan moral ataupun pendidikan karakter yang ada dalam konteks sekarang sangat relevan untuk mengatasi krisis moral yang sudah melanda di negara kita. Krisis tersebut berupa banyaknya pergaulan bebas, maraknya angka kekerasan terhadap anak-anak dan remaja, pencurian remaja, kejahatan terhadap teman, kebiasaan menyontek, pornografi, penyalahgunaan obat-obatan, dan perusakan milik orang lain yang yelah menjadi masalah social sehingga pada saat ini belum bisa diatasi secara tuntas. Oleh karena itu betapa sangat pentingnya karakter pada pendidikan.

Para ahli pendidikan karakter melihat proses internalisasi nilai dalam pembelajaran, termasuk internalisasi pendidikan karakter di Madrasah pada dua pendekatan. Pertama, Madrasah secara terstruktur mengembangkan pendidikan karakter melalui kurikulum formal. Kedua, pendidikan karakter berlangsung secara alamiah dan sukarela melalui jalinan hubungan interpersonal antar warga madrasah, meski hal ini tidak diatur secara langsung dalam kurikulum formal.

Pada beberapa madrasah yang memanfaatkan peluang-peluang belajar di luar kelas sebagai wahana pengembangan pendidikan, kegiatan ektrakuriluler muncul sebagai keunggulan tersendiri yang pada giliranya melahirkan kredibilitas tersendiri bagi lembaga. Tidak jarang kita dengar alasan-alasan orang tua dalam memilih sekolah sebagai tempat belajar anaknya atas dasar pertimbangan mereka terhadap sejumlah kegiatan di luar kegiatan tatap muka di kelas. Dengan demikian, kegiatan ektrakurikuler dapat dikembangkan dalam 
Jito Subianto

beragam cara sebagai media pendidikan karakter. Penyelenggaraan kegiatan yang memberikan kesempatan luas kepada pihak madrasah, pada giliranya menuntut kepala madrasah, guru, siswa dan pihakpihak yang terkait untuk secara efektif merancang sejumlah kegiatan sebagai muatan kegiatan ektrakurikuler berbasis pendidikan karakter.

Dengan masing masing peran yang dilakukan dengan baik oleh keluarga, sekolah maupun masyarakat dalam pendidikan, yang saling memperkuat dan saling melengkapi antara ketiga pusat itu, akan memberi peluang besar mewujudkan sumber daya manusia terdidik yang bermutu. 


\section{DAFTAR PUSTAKA}

Arsyad, S.A. 2010. Character Education, Disajikan Pada Sarsehan Nasional Pendidikan Karakter. Dikti Kementerian Pendidikan Nasional di Hotel Murcure Pontianak, Tanggal 17 April 2010.

Aunurrahman. 2009. Eksistensi dan Arah Pendidikan Nilai. Pontianak: STAIN Pontianak Press.

Azra, Azyumardi, 2003 (cetakan 2, 2006), Paradigma Baru Pendidikan Nasional: Rekonstruksi dan Demokratisasi. Jakarta: Penerbit Kompas.

Azra, Azyumardi, 1999a, "Membangun Kembali Karakter Bangsa: Peran dan Tantangan Perguruan Tinggi", makalah disampaikan pada Dies Natalis ke-50 Universitas Gadjah Mada, 13 Nopember 1999.

Azra, Azyumardi, 1999b, "Pembinaan Pendidikan Akhlak Didik pada Era Reformasi", pokok-pokok pikiran untuk Seminar tentang Pendidikan Anak dalam Indonesia Baru, Direktorat Pembinaan Pendidikan Islam pada Sekolah Umum, Depag RI, Jakarta, 2 Nopember 1999.

Ayu S. Sadewo. 2009. Mudahnya Mendidik Anak Beda Karakter dan Bakat, Beda Perlakukan. Jakarta: Penebar Swadaya.

Aziz Hamka Abdul. 2011. Pendidikan Karater berpusat pada Hati. Jakarta: Almawardi Prima

Bagir, Zainal Abidin dkk. 2005. Integrasi Ilmu dan Agama, Interpretasi dan Aksi. Bandung: Mizan Pustaka

Fraenkel, Jack R. 1977. How to Teach about Values: An Analytical Approach, Englewood, NJ: Prentice Hall.

Ibn Miskawaih. 1992. Filsafat Akhlak. Bandung: Mizan.

Keosoema, Doni. 2009. Pendidikan Karakter. Jakarta: Grasindo

Keosoema, Doni 2007. Pendidikan Karakter, strategi mendidik anak di zaman gobal. Jakarta: Grasindo

Keosoema, Doni. 2009. Pendidikan Karakter di zaman keblinger. Jakarta: Grasindo 
Jito Subianto

Keosoema, Doni. 2010. Pendidikan Karakter Integral. Kompas, 11 Februari 2010

Kirschenbaum, Howard \& Sydney B. Simon. 1974. Values and Futures Movement in Education, dalam Alvin Toffler (ed.), Learning for Tomorrow: The Role of the Future in Education, New York: Random House.

M. Anis Matta, 2006. Membentuk Karakter Cinta Islam, Jakarta: alI'tishom Cahaya Umat.

Mulyana Rahmat. 2004. Mengartikulasikan Pendidikan Nilai, Bandung; Alfabeta.

Mulyo, Karso. 2009. Membangun Karakter Bangsa melalui Pembelajaran kontektual. Tersedia, online: http//mitrawacanawrc.com.

Munir Abdullah. 2010. Pendidikan Kalakter. Yogyakarta: Pedagogia.

Nata Abuddin, dkk. 2002. Integrasi Ilmu Agama dan Ilmu Umum. Jakarta; Raja Grafindo Persada

Sulhan, Najib. 2010. Pendidikan Berbasis Karakter. Surabaya: Jape Press Media Utama (Jawa Pos Grup).

Q-Anees Bambang, Hambali Adang. 2008. Pendidikan Kalakter Berbasis Al-Quran. Bandung: Simbiosa Rekatama Media.

Sadulloh Uyoh 2003. Pengantar Filsafat Pendidikan, Bandung; Alfabeta.

Shihab, M. Quraish. 1996. Wawasan al-Qur'an: Tafsir Maudhu'I atas Pelbagai Persoalan Umat. Bandung: Mizan.

Sauri, S. 2006. Pendidikan Berbahasa Santun. Bandung: Genesindo

Suwito. 2004. Filsafat Pendidikan Etika Ibnu Miskawaih, Yogyakarta, Belukar

Soebahar Abd Halim. 2002. Wawasan Baru Pendidikan Islam.Kalam Mulia. Jakarta

Supriyatno, Triyo 2009. Pendidikan Karakter di Sekolah. Tersedia, online, http://kahmiuin.blogspot.com.

Phillips, C. Thomas. 2000. Family as the School of Love. Makalah pada National Conference on Character Building, Jakarta, 25-26 Nopember, 2000. 